\title{
Tourists' Mindset, Level of Satisfaction and the Role of Brands Towards Shaping Them
}

\author{
Kahkasha Wahab \\ Lecturer \\ Department of International Tourism and Hospitality Management, Primeasia University \\ Star Tower, 12 Kemal Ataturk Avenue, Banani, Dhaka 1213
}

\begin{abstract}
Bangladesh is the land of different tourist destinations. These destinations can help Bangladesh to earn billions of foreign revenue, if nurtured properly. But the misfortune is, these destinations fail to satisfy the needs and expectations of the tourists. The primary reason behind this is lack of research conducted by the destination management organizations regarding the demands of foreign travelers, based on specific destinations. This research has been undertaken to evaluate the ways and scopes for satisfying the tourist's need, considering tourist's as the consumers of tourism products. This study has been conducted on 200 respondents through self-administered questionnaire. The primary and secondary information has been collected and the quantitative data has evaluated through Statistical Package for Social Sciences (SPSS). Various descriptive and statistical analysis have been led to discover the present situation of the tourist's mindset. Correlation analysis, multiple regression analysis, T-test, Chi-square test, etc. have been directed to validate data accuracy. At the end of this study, some recommendations have been provided that may help the tourism industry to flourish and create permanent tourists, who would love to visit the country again and again as repeat visitors.
\end{abstract}

Keywords: Consumer satisfaction, tourists, branding

DOI: $10.7176 / \mathrm{EJBM} / 13-11-08$

Publication date:June $30^{\text {th }} 2021$

\section{Introduction}

Bangladesh has a lot of potential tourist destinations. Historical landmarks, beaches, resorts, picnic areas, woodland, indigenous people and diverse types of wildlife are among the mentionable tourist attractions.

Tourists' experiences include cultural activities, natural beauty, sailing, skiing, river cruising, cycling, yacht rowing and sea surfing. Tourists love to perform the above activities while they visit a destination. Besides, the tourists consume a lot of products like the national foods, street foods and different kind of cakes. They also enjoy different culture of a country as well as nature of the destination. Tourist's destinations must have to keep the arrangement in such a way that both domestic and foreign tourists can be satisfied.

Every year a lot of domestic and foreign tourists visit different destinations of our country. But the tourist faces a lot of problems and they become dissatisfied for this. The most important thing in any industry is the customer satisfaction (Chakraborty, J., 2012). Bangladesh has a lot of destinations that can easily attract the tourist's eye. Tourists basically travel for enjoying the beauty of a destination and get some relaxations. So, it is the best opportunity to bring foreigners in the country. It can satisfy the tourists by its beautiful destination. If it is possible to satisfy the tourists it will be very easy to prosper in this sector. By satisfying the tourists a country can develop its brand image like the brand name of Bangladesh is "Beautiful Bangladesh".

\section{Background and significance}

Bangladesh has many disadvantages but it also has many advantages of tourism site (Teel, J.E., 2007). By this ending this and solving the problem of tourism we introduce the nation in other world and earn much more money in same time we develop the country.

In many countries tourism is established and is consider as the most important sector for the economy. Maldives and Malaysia are two significant examples of tourist developed countries. Their economy is boosting up through the hand of tourism sector. So, tourism has a prosperous future in building up a country's economy as well as establish itself as a developed country.

\section{Scope of the study}

As this study is on the consumer satisfaction there are lots of scopes for satisfying the consumer as well as conducting the research. With the assistance of technologies and infrastructure in relation to the globalization process, operation has been massively extended in this sector.

The goal of this paper is to analyze the degree and potential of tourism growth in Bangladesh and to concentrate on the environment, nature and services of Bangladesh and its natural and cultural heritage. The potentiality of the tourism sector is increasing day by day. There is a lack of research on the tourism sector in the country. It has huge scope to conduct research on the sector. 


\section{Rational of the study}

Tourists always want to get best services while travelling a destination as a single mess may destroy all the pleasure. To satisfy the consumer of the industry the manager of a destination has to provide notable service to the tourists. The manager has to identify the needs and demands of a tourist at a proper time. It is very difficult to find out the consumers demands at the destination. So, here it has been tried to find out the things that may affect the consumer satisfaction (Fisher, R.A., (2002).

\section{Objectives of the study}

A tourist travels for enjoying his/ her free time and for different purposes like business, health etc. Generally, a tourist revisits to the destinations, in which $\mathrm{s} / \mathrm{he}$ feels satisfied or feels safe to travel. A repeat customer is the customer who travels a destination again and again.

To satisfy customer is very tough but it is possible if the factors can be identified by which s/he may satisfy. So, the main objective of this report is to find out how to satisfy the customers.

\section{The secondary objectives include:}

- To identify the factors that affect the consumer satisfaction

- To find out the ways to improve

- To satisfy the consumers demand

\section{Statement of the problem}

Bangladesh has innumerable potentialities for tourism industry as it has many beautiful destinations. The natural beauty of Bangladesh is beyond descriptions. Though it has so many wonderful destinations it cannot attract foreign tourists. The main problem is that the destinations cannot satisfy the foreign tourists.

It has so many reasons like infrastructure problem, poor management, lack of branding, destinations facilities, poor sanitation facilities, lack of enough information and so many (Morgan, D.W., 2004).

Bangladesh is not a developed country. The people of the country are not aware of the tourism and a large number of people are illiterate. The country needs to aware people about the prospects of the tourism. Only then the problems can be reduced.

\section{Literature review}

Consumer is very crucial term in tourism as the success of tourism industry depends on it. Many researchers have tried to clarify the contribution of consumer satisfaction. Different writers wrote different papers on consumer satisfaction like Jeffery Gitomer and Anne Minor. Several problems have to be taken into account in the creation and usage of resources for satisfaction interventions in the tourism industry in the form of community services (Balmer, J.M., 2001).

Tourism is a unique and varied field, and its promotion should be targeted at a wide number of people with different preferences, studies, expectations, ambitions, and behavioral habits in various countries with different socio-economic systems. Designing an effective campaign advertising strategy must then infiltrate the preferences and expectations of people (Shafi, 1985). Jahangir (1998) argued that in the South Asian zone, Bangladesh's share of total arrivals is too small. Almost all South Asian nations are well ahead of Bangladesh in terms of tourism growth, supported by concerted efforts (Morgan, D.W., 2004). In the literature, there is a growing presumption that people and their families should be at the forefront of program creation, implementation and analysis. To evaluate satisfaction, the techniques and procedures of this study need to be tailored to the specific needs and preferences of literacy, pacing, and form. There are also hopes that the members will gain information on their input and suggestions about the wider implications of these processes (Kalagnanam, J.R., 2005).

\subsection{Consumer satisfaction:}

Tourists come to visit a destination and to enjoy their holidays. They come and get satisfied by the destination and other services. A destinations manager has the responsibility to satisfy the consumers who directly consume the tourism product. The main target of every business is to satisfy the target customers. So consequently the tourism destinations also have to satisfy the tourists. It increases the reputation of the destinations and also generates a lot of revenue. (Balmer, J.M., 2001).

\subsection{Branding:}

Branding is like a distinct logo or icon by which we can understand the thing at a first sight. It is the most significant element of a destination as it provides the overall information about the specific destination or something like that. Without proper branding it is not possible to attract the domestic and foreign tourist (Balmer, J.M., 2001).

\section{Methodology}

As consumer satisfaction is the main instrument for the development of any business it is important to identify the 
method. The methods depend on the topic and the reporter as it has a specific rules.

Population is the each and every unit of research that has been conducted. Population size is larger than the sample size as it represents the whole population. The population size in this research is all the consumers who consume the tourism products. The population size is denoted by $\mathrm{N}$.

Sample is the part of population and it represents the feature of all the population.

The sample size is represented by $\mathrm{n}$. In this research, Sample, $\mathrm{n}=200$

The research may be both qualitative and quantitative. Basically as the research I want to conduct on consumer satisfaction it may be qualitative research.

Both qualitative and quantitative data has been used in this study. The qualitative data helps to identify the actual condition of tourism in a country. Besides, it can be converted into quantitative data if necessary. The research has mainly focused on the problems of the tourists and the demand of the tourists. It has also helped to understand the problems easily and to solve the problems.

In tourism quantitative and qualitative research may require but for the survey on consumer satisfaction and branding qualitative research has been the most appropriate one as it requires a lot of qualitative information (Lincoln, Y.S., 12009).

While making the analysis findings of this research the data plays key role. Both primary and secondary data has been used while conducting this research. In the primary source, questionnaire has been designed to collect data from different respondents and for making the analysis. The questionnaire is basically on the consumer satisfaction and it has facilitated the way of understanding of the consumer demand. As tourism is a large and flourish industry it has a great source of secondary data. Furthermore, the secondary data has been collected from different articles books and institutions, five star hotels and restaurant, Bangladesh tourism board and Bangladesh Parjatan Corporation. These organizations provide authentic information or data that has been very helpful for conducting the research. The secondary sources provide the present number of tourists, revenue from tourism, contribution of tourism etc.

\section{The branding process}

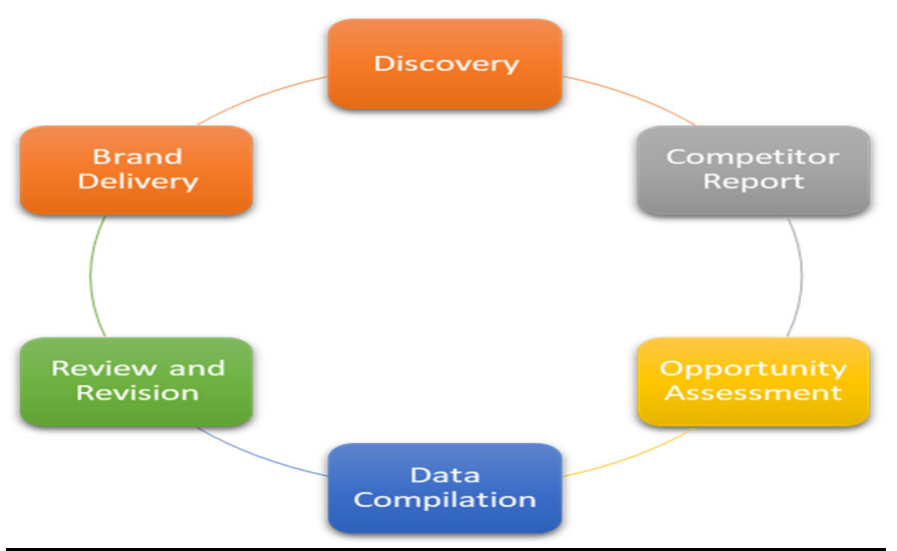

Figure 1: Branding process

Source: (Balmer, J.M., 2001).

Branding is one of the most important factors that affect the consumer. Branding means to differentiate the country or the destination. The tourists can easily differentiate the country by its specific brand name. The above illustration illustrates the branding process. At first the brand should be discover and deliver to the tourists. It should have proper brand equity for any type of consumers. Branding a country is not easy and it must have some qualitative features. Proper band communication is needed after creating the brand name as it will have a value. Brand name and slogan makes the consumer clarified about the features of the destinations of a country. Those who are very fond of nature, will come and visit Bangladesh for pleasure.

\section{Limitations of the study}

On this particular topic there may have different limitations of this study as it is not developed. The limitations are- Scarcity of data, limited respondents, expensive, time consuming, lack of knowledge of the people, less distribution channels. These may be the limitations of the study. While conducting the research on consumer satisfaction the researchers have faced these limitations. 


\section{Data analysis}

11.1 Crosstab

Case Processing Summary

\begin{tabular}{|c|c|c|c|c|c|c|}
\hline \multicolumn{7}{|c|}{ Cas } \\
\hline & \multicolumn{2}{|c|}{ Valid } & \multicolumn{2}{|c|}{ Missing } & \multicolumn{2}{|c|}{ Total } \\
\hline & $\mathbf{N}$ & Percent & $\mathbf{N}$ & Percent & $\mathbf{N}$ & Percent \\
\hline \multicolumn{7}{|c|}{ I love to travel } \\
\hline Gender & 200 & $100 \%$ & $\mathbf{0}$ & $0 \%$ & 200 & $100 \%$ \\
\hline Age & 200 & $100 \%$ & $\mathbf{0}$ & $0 \%$ & 200 & $100 \%$ \\
\hline Occupation & 200 & $100 \%$ & $\mathbf{0}$ & $0 \%$ & 200 & $100 \%$ \\
\hline Income & 200 & $100 \%$ & $\mathbf{0}$ & $0 \%$ & 200 & $100 \%$ \\
\hline \multicolumn{7}{|c|}{ I have a fascination in travelling } \\
\hline Gender & 200 & $100 \%$ & $\mathbf{0}$ & $0 \%$ & 200 & $100 \%$ \\
\hline Age & 200 & $100 \%$ & $\mathbf{0}$ & $\mathbf{0 \%}$ & 200 & $100 \%$ \\
\hline Occupation & 200 & $100 \%$ & $\mathbf{0}$ & $\mathbf{0 \%}$ & 200 & $100 \%$ \\
\hline Income & 200 & $100 \%$ & $\mathbf{0}$ & $\mathbf{0 \%}$ & 200 & $100 \%$ \\
\hline \multicolumn{7}{|c|}{ The service of destinations in Bangladesh is very good } \\
\hline Gender & 200 & $100 \%$ & $\mathbf{0}$ & $\mathbf{0 \%}$ & 200 & $100 \%$ \\
\hline Age & 200 & $100 \%$ & $\mathbf{0}$ & $\mathbf{0 \%}$ & 200 & $100 \%$ \\
\hline Occupation & 200 & $100 \%$ & $\mathbf{0}$ & $\mathbf{0 \%}$ & 200 & $100 \%$ \\
\hline Income & 200 & $100 \%$ & $\mathbf{0}$ & $\mathbf{0 \%}$ & 200 & $100 \%$ \\
\hline \multicolumn{7}{|c|}{ Sanitation facilities should be increased in Bangladesh } \\
\hline Gender & 200 & $100 \%$ & $\mathbf{0}$ & $\mathbf{0 \%}$ & 200 & $100 \%$ \\
\hline Age & 200 & $100 \%$ & $\mathbf{0}$ & $\mathbf{0 \%}$ & 200 & $100 \%$ \\
\hline Occupation & 200 & $100 \%$ & $\mathbf{0}$ & $\mathbf{0 \%}$ & 200 & $100 \%$ \\
\hline Income & 200 & $100 \%$ & $\mathbf{0}$ & $0 \%$ & 200 & $100 \%$ \\
\hline
\end{tabular}

I have a fascination in travelling * gender

Table - 1: Case Processing Summary

\begin{tabular}{|l|l|l|l|l|}
\hline \multicolumn{2}{|l|}{ Crosstab } \\
\hline Count & \multicolumn{3}{l|}{ gender } & Total \\
\cline { 3 - 6 } & male & female & \\
\hline I have a fascination in travelling & strongly agree & 84 & 3 & 87 \\
& & & & \\
\cline { 2 - 6 } & agree & 94 & 7 & 101 \\
\cline { 2 - 6 } & neutral & 11 & 1 & 12 \\
\hline Total & & 189 & 11 & 200 \\
\hline
\end{tabular}

\begin{tabular}{|l|l|l|l|}
\hline \multicolumn{3}{|l|}{ Chi-square test: } \\
\hline & Value & df & Asymp. Sig. (2-sided) \\
\hline Pearson Chi-Square & $1.288^{\mathrm{a}}$ & 2 & .525 \\
\hline Likelihood Ratio & 1.338 & 2 & .512 \\
\hline Linear-by-Linear Association & 1.220 & 1 & .269 \\
\hline N of Valid Cases & 200 & & \\
\hline a. 2 cells $(33.3 \%)$ have expected count less than 5. The minimum expected count is .66. \\
\hline
\end{tabular}

Table -2: Crosstab: I have a fascination in travelling * gender

Table -3: Crosstab: Chi-square test

By conducting the chi-square test, it has been found that the value of chi square is 1.288 that is smaller than the benchmark of 1.5. It indicates that there is a statistically significant relationship between observed and predicted variable. Here the predicted variable includes the above mentioned four variables and the predicted variable is consumer satisfaction. Therefore it is proved that the consumer satisfaction is influenced by the predicted variable. 


\subsection{T-Test Group Statistics}

\begin{tabular}{|l|l|l|l|l|l|}
\hline & gender & $\mathbf{N}$ & Mean & $\begin{array}{l}\text { Std. } \\
\text { Deviation }\end{array}$ & $\begin{array}{l}\text { Std. } \\
\text { Mean }\end{array}$ \\
\hline The tourism products in Bangladesh are very & male & $\mathbf{1 8 9}$ & $\mathbf{2 . 0 9 5 2}$ & $\mathbf{2 . 9 4 4 7 8}$ & .21420 \\
\hline & female & $\mathbf{1 1}$ & $\mathbf{2 . 1 8 1 8}$ & $\mathbf{. 7 5 0 7 6}$ & $\mathbf{. 2 2 6 3 6}$ \\
\hline
\end{tabular}

Table -4: T-Test Analysis

\section{HYPOTHESIS DEVELOPMENT}

In testing hypothesis, we first state the null hypothesis and the alternate hypothesis. We have 8 independent variables such as $\lambda_{1}, \lambda_{2}, \lambda_{3}, \lambda_{4}, \lambda_{5}, \lambda_{6}, \lambda_{7}, \lambda_{8}$ are simple regression coefficients. The corresponding coefficients in the population are given in the symbol $\beta_{1}, \beta_{2}, \beta_{3}, \beta_{4}, \beta_{5}, \beta_{6}, \beta_{7}, \beta_{8}$

The null hypothesis is: $\mathbf{H}_{0}: \boldsymbol{\beta}_{1}=\boldsymbol{\beta}_{2}=\boldsymbol{\beta}_{3}=\boldsymbol{\beta}_{4}=\boldsymbol{\beta}_{5}=\boldsymbol{\beta}_{6}=\boldsymbol{\beta}_{7}=\boldsymbol{\beta}_{8}=0$

The alternate hypothesis is: $H_{1}$ : Not all the $\beta$ 's are 0

If the null hypothesis is true, it implies the regression coefficients is 0 and logically are of no use in estimating the dependent variable. We have to search some for other independent variable to the consumer satisfaction.

\section{DESCRIPTIVE STATISTICS}

\begin{tabular}{|l|l|l|l|}
\hline Descriptive Statistics & $\mathbf{N}$ & Mean & Std. Deviation \\
\hline Gender & $\mathbf{2 0 0}$ & $\mathbf{1 . 0 5 5 0}$ & $\mathbf{. 2 2 8 5 5}$ \\
\hline Age & $\mathbf{2 0 0}$ & $\mathbf{2 . 6 6 5 0}$ & $\mathbf{. 6 2 0 2 4}$ \\
\hline Occupation & $\mathbf{2 0 0}$ & $\mathbf{1 . 1 3 5 0}$ & $\mathbf{. 4 8 7 8 2}$ \\
\hline Income & $\mathbf{2 0 0}$ & $\mathbf{1 . 1 4 5 0}$ & $\mathbf{. 5 4 3 5 6}$ \\
\hline I love to travel & 200 & 1.3950 & .49006 \\
\hline The tourism products in Bangladesh are very attractive & 200 & 2.1000 & 2.86724 \\
\hline I have a fascination in travelling & 200 & 1.6250 & .59679 \\
\hline Infrastructure is most important in the development of tourism & 200 & 1.5700 & .63807 \\
\hline Natural destinations are more preferable than human made destinations. & 200 & 1.6500 & .60774 \\
\hline Good accommodation facilities are necessary for tourists. & 200 & 1.6305 & .54313 \\
\hline More effective tour guides are required for proper guideline of the tourists & 200 & 2.0500 & .71418 \\
\hline The safety and security system should be developed in Bangladesh & 200 & 1.5650 & .57220 \\
\hline Bangladesh needs to create brand image & 200 & 1.6850 & .59797 \\
\hline The service of destinations in Bangladesh is very good & 200 & 2.7600 & 1.06207 \\
\hline I love the ethnic culture of Bangladesh & 200 & 2.1110 & .81806 \\
\hline I have travelled most of the destinations of Bangladesh & 200 & 2.4000 & 1.01248 \\
\hline Sanitation facilities should be improved in Bangladesh & 200 & 2.0550 & .82789 \\
\hline I travel at least once in a year in Bangladesh & 200 & 1.3850 & .51780 \\
\hline Overall, I am satisfied after visiting Bangladesh & 200 & 2.6500 & .86093 \\
\hline Valid N (listwise) & 200 & & \\
\hline
\end{tabular}

Table -5: Descriptive Analysis 


\section{PIE-CHART ON TOURIST SATISFACTION}

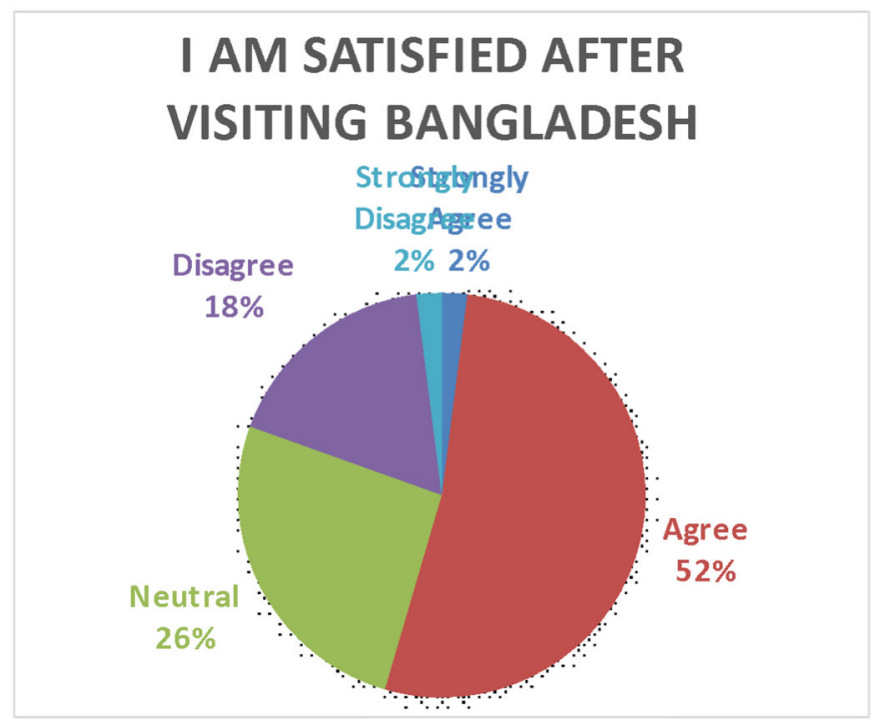

Figure 2: Pie-chart on tourist's satisfaction

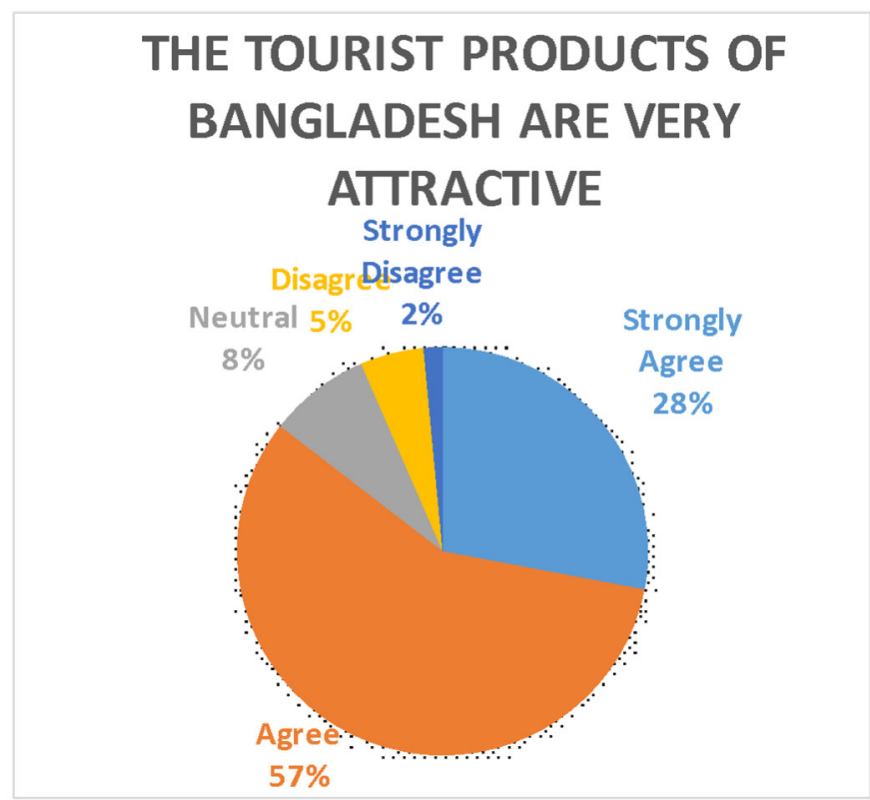

Figure 3: Pie-chart on tourist's products

15. CORRELATION ANALYSIS

"Correlation is a statistical technique that can show whether and how strongly pairs of variables are related. Correlation defines the quantifiable data in which numbers are meaningful, usually quantities of some sort. It may not be used for purely categorical data, such as gender and brands purchased" (Fisher, R.A., (2002). 


\begin{tabular}{|c|c|c|c|c|c|c|c|}
\hline \multicolumn{8}{|c|}{ Correlations } \\
\hline & & 㐫 & 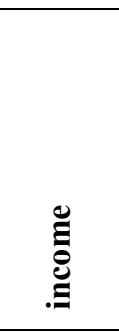 & $\begin{array}{l}\text { The } \\
\text { tourism } \\
\text { products in } \\
\text { Bangladesh } \\
\text { are very } \\
\text { attractive }\end{array}$ & $\begin{array}{l}\text { Good } \\
\text { accommodation } \\
\text { facilities are } \\
\text { needed for } \\
\text { tourists. }\end{array}$ & $\begin{array}{l}\text { The safety } \\
\text { and } \\
\text { security } \\
\text { system } \\
\text { should be } \\
\text { developed } \\
\text { in } \\
\text { Bangladesh }\end{array}$ & $\begin{array}{l}\text { Infrastructure } \\
\text { is most } \\
\text { important in } \\
\text { the } \\
\text { development } \\
\text { of tourism }\end{array}$ \\
\hline \multirow{3}{*}{ gender } & $\begin{array}{l}\text { Pearson } \\
\text { Correlation }\end{array}$ & 1 & -.024 & .007 & .124 & -.085 & -.044 \\
\hline & $\begin{array}{l}\text { Sig. } \\
\text { tailed) }\end{array}$ & & .735 & .923 & .080 & .231 & .538 \\
\hline & $\mathbf{N}$ & 200 & 200 & 200 & 200 & 200 & 200 \\
\hline \multirow{3}{*}{ income } & $\begin{array}{l}\text { Pearson } \\
\text { Correlation }\end{array}$ & -.024 & 1 & -.016 & .080 & $-.184^{* *}$ & .050 \\
\hline & $\begin{array}{l}\text { Sig. } \\
\text { tailed) }\end{array}$ & .735 & & .824 & .259 & .009 & .480 \\
\hline & $\mathbf{N}$ & 200 & 200 & 200 & 200 & 200 & 200 \\
\hline \multirow{3}{*}{ 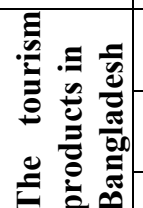 } & $\begin{array}{l}\text { Pearson } \\
\text { Correlation }\end{array}$ & .007 & -.016 & 1 & .075 & .011 & .035 \\
\hline & $\begin{array}{l}\text { Sig. } \\
\text { tailed) }\end{array}$ & .923 & .824 & & .288 & .873 & .627 \\
\hline & $\mathbf{N}$ & 200 & 200 & 200 & 200 & 200 & 200 \\
\hline \multirow{6}{*}{ 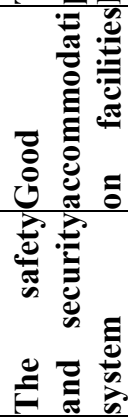 } & $\begin{array}{l}\text { Pearson } \\
\text { Correlation }\end{array}$ & .124 & .080 & .075 & 1 & -.036 & .060 \\
\hline & $\begin{array}{l}\text { Sig. } \\
\text { tailed) }\end{array}$ & .080 & .259 & .288 & & .610 & .400 \\
\hline & $\mathbf{N}$ & 200 & 200 & 200 & 200 & 200 & 200 \\
\hline & $\begin{array}{l}\text { Pearson } \\
\text { Correlation }\end{array}$ & -.085 & $-.184^{* *}$ & .011 & -.036 & 1 & -.019 \\
\hline & $\begin{array}{l}\text { Sig. } \\
\text { tailed) }\end{array}$ & .231 & .009 & .873 & .610 & & .785 \\
\hline & $\mathbf{N}$ & 200 & 200 & 200 & 200 & 200 & 200 \\
\hline \multirow{3}{*}{ 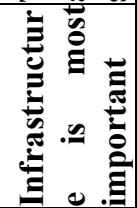 } & $\begin{array}{l}\text { Pearson } \\
\text { Correlation }\end{array}$ & -.044 & .050 & .035 & .060 & -.019 & 1 \\
\hline & $\begin{array}{l}\text { Sig. } \\
\text { tailed) }\end{array}$ & .538 & .480 & .627 & .400 & .785 & \\
\hline & $\mathbf{N}$ & 200 & 200 & 200 & 200 & 200 & 200 \\
\hline
\end{tabular}

Table -6: Correlation analysis

\section{MULTIPLE REGRESSION ANALYSIS}

Mainly two multiple regression models have been used to run the analysis. First Multiple Regression Model has been used to know how different independent variable of the consumer satisfaction affects the dependent variable. Multiple Regression Model-1:

How different independent variables of the consumer satisfaction affect the dependent variable.

Multiple Regression Equation: $\mathrm{Y}=\alpha+\beta 1 \lambda 1+\beta 2 \lambda 2+\beta 3 \lambda 3+\beta 4 \lambda 4+\beta 5 \lambda 5+\beta 3 \lambda 6+\beta 4 \lambda 7+\beta 5 \lambda 8$

Here,

Dependent Variable:

$\mathrm{Y}=$ Consumer satisfaction

Independent Variable:

$\lambda 1=$ Tourism products

$\lambda 2=$ Infrastructure

$\lambda 3=$ Natural destination

$\lambda 4=$ Accommodation facilities

$\lambda 5=$ Safety and security

$\lambda 6=$ Brand image 
$\lambda 7=$ Service of the destination

$\lambda 8=$ Sanitation facilities

\section{MODEL SUMMARY}

\begin{tabular}{|c|c|c|c|c|c|c|c|c|c|}
\hline \multirow[t]{2}{*}{ Model } & \multirow[t]{2}{*}{$\mathrm{R}$} & \multirow[t]{2}{*}{ R Square } & \multirow{2}{*}{$\begin{array}{l}\text { Adjusted } \\
\text { R Square }\end{array}$} & \multirow{2}{*}{$\begin{array}{l}\text { Std. Error } \\
\text { of the Estimate }\end{array}$} & \multicolumn{5}{|c|}{ Change Statistics } \\
\hline & & & & & $\begin{array}{l}\text { R Square } \\
\text { Change }\end{array}$ & F Change & df1 & $\mathrm{df} 2$ & $\begin{array}{l}\text { Sig. F } \\
\text { Change }\end{array}$ \\
\hline 1 & $.500^{\mathrm{a}}$ & .250 & .176 & .78162 & .250 & 3.357 & 18 & 181 & .000 \\
\hline
\end{tabular}

\begin{tabular}{|l|l|l|l|l|l|l|}
\hline \multicolumn{7}{|l|}{} \\
\hline Model & Sum of Squares & df & Mean Square & F & Sig. \\
\hline \multirow{1}{*}{1} & Regression & 36.921 & 18 & 2.051 & 3.357 & $.000^{\mathrm{b}}$ \\
\cline { 2 - 7 } & Residual & 110.579 & 181 & .611 & & \\
\cline { 2 - 6 } & Total & 147.500 & 199 & & & \\
\hline Table -8: ANOVA \\
\begin{tabular}{l} 
a. Dependent Variable: Overall, I am satisfied in visiting Bangladesh \\
\hline
\end{tabular} \\
b. Predictors: (Constant)
\end{tabular}

Table -7: Model Summary

a. Predictors: (Constant), I travel at least once in a year in Bangladesh, I love to travel, I have a fascination in travelling, Infrastructure is most important in the development of tourism, The tourism products in Bangladesh are very attractive, occupation, Sanitation facilities should be increased in Bangladesh, Bangladesh needs to create brand image, Natural destinations are more preferable than human made destinations., I travel most of the destinations of Bangladesh, The service of destinations in Bangladesh is very good, More effective tour guides are required for proper guideline of the tourists, Good accommodation facilities are needed for tourists., The safety and security system should be developed in Bangladesh, gender, I love the ethnic culture of Bangladesh, age, income.

Here, $\mathrm{R}=0.50$ means that there is strong positive relationship among the independent variables and the dependent variable.

The model summary shows some important indicators of the explanatory power of the model. The R-square value shows the percentage of variation in the dependent variable is explained by the set of independent variables and it is . 250 .

On the other hand, the Adjusted R-square value shows the percentage of variation in the dependent variable is explained by the statistically significant independent variables.

In this case, Adjusted R-square value of .176 means that the statistically significant independent variables can explain .176 of the variation in labor productivity and it also indicates the model has the strong predictive power. If we compare R-Square .250 to the adjusted R-square .a76, the difference in this case is small (Fisher, R.A., (2002).

\section{ANOVA}

The ANOVA table shows the total variation, regression variation and residual error or error variance. The regression variation is denoted as SSR and the residual error is denoted by SSE. The total variation (SST) is 147.500 and variation explained by regression variation (SSR) is 36.921 and residual error (SSE) is 110.579 . If we divide the SSR by SST, we get the value of R-square which we have already found out to be $25 \%$.

\section{RECOMMENDATIONS}

It is very difficult to understand human mind. Thus it is more critical to understand tourist's wants and demands. Generally people want to visit a destination to get pleasure but sometimes they feel bored while staying in a destination. Tourism comprises not only a single product but consists a lot of products including the air or bus ticket to food. All these facilities and services provide tourist's satisfaction. Though it is tough to satisfy a person but maximum output should be given to tourism. As Bangladesh is a developing country there are a lot of problems in tourism sector. Some recommendations can be pointed from this research. They are:

- Developing the infrastructure

- Developing the accommodation facilities

- Establishing bar and gaming facilities for the foreign tourists

- Reducing political instability especially in tour zones.

- Making local people aware of the tourists

- Developing the country's image 
- Appointing traffic police in tourists destination

- Establishing high safety and security for the consumers

- Creating a website to easy access of information

- Making sanitation facilities available

To solve the various problems that lack behind the country we can use the above recommendations.

\section{DISCUSSIONS}

Every year a lot of tourists visit the different places in Bangladesh especially in Cox's bazar, Kuakata sea beach, Saint Martin, Bandarban, Sylhet and Chittagong. These places are popular in both domestic and foreign tourists. Foreign tourists like the natural destinations of Bangladesh. If the foreign tourists visit the country it will help to boost up the economy. In this case, the organizer of a destination has to satisfy the foreign tourist by providing the necessary facilities to the tourists.

Sometimes tourist may complain of any mismanagement, then the main responsibility of the DMO is to find out the fault and correct it. It is very much sensitive to satisfy the foreign tourists as their ways of life is different than ours (Ho, A., 2007). The responsible authority should take especial care of the foreign tourists. If it is possible to satisfy the consumer they will again visit the country.

Every tourist is the ultimate consumer of the tourism product. The overall condition of tourism is monitored by Bangladesh Tourism Board and Bangladesh Parjatan Corporation.

\section{CONCLUSION}

Tourists are like life of tourism industry. It is now important to satisfy the every need of a tourist for meeting their demand. Above all this research will become a significant instrument to develop the customer satisfaction as well as the tourism industry. For this reason a country has to emphasize on tourism sector and should conduct several research on the development of tourist satisfaction. It is an industry that utilizes the natural resources in an effective way. The potentiality of tourism sector is baggers description. As the main motive tourism industry is to satisfy the consumer we have to solve all the problems and provide the essential commodities to the consumer. Comfort is another important factor for attracting the tourists. For satisfying the tourists we have to deliver all the facilities promptly. Actually, satisfaction is psychological factor and also sensitive. So, it may vary consumer to consumer. Overall, if it is possible to satisfy the consumer it will promote the tourism sector very fast.

\section{References}

Balmer, J.M., (2001). Corporate identity, corporate branding and corporate marketing-Seeing through the fog. European journal of marketing, 35(3/4), pp.248-291.

Bearden, W.O. and Teel, J.E., (2007). Selected determinants of consumer satisfaction and complaint reports. Journal of marketing Research, pp.21-28.

Das, R.K. and Chakraborty, J., (2012). An evaluative study on tourism in Bangladesh. Developing Country Studies, 2(1), pp.17-27.

Denzin, N.K. and Lincoln, Y.S., 1(2009). Handbook of qualitative research. Sage publications, inc.

Diwekar, U.M. and Kalagnanam, J.R., (2005). Efficient sampling technique for optimization under uncertainty. AIChE Journal, 43(2), pp.440-447

Fisher, R.A., (2002). Frequency distribution of the values of the correlation coefficient in samples from an indefinitely large population. Biometrika, 10(4), pp.507-521.

Hox, J.J. and Boeije, H.R., (2005). Data collection, primary vs. secondary. Encyclopedia of social measurement, $1(1)$, pp.593-599.

Hui, T.K., Wan, D. and Ho, A., (2007). Tourists' satisfaction, recommendation and revisiting Singapore. Tourism management, 28(4), pp.965-975.

Krejcie, R.V. and Morgan, D.W., (2004). Determining sample size for research activities. Educational and psychological measurement, 30(3), pp.607-610.

Neuman, L.W., 2002. Social research methods: Qualitative and quantitative approaches.

Woodside, A.G., Frey, L.L. and Daly, R.T., (2008). Linking Sort/ice anlity, Customer Satisfaction, and Behavioral Intention. Journal of health care marketing, 9(4), pp.5-17. 